\title{
Disinfecting Water with the Carbon Fiber-Based Flow-Through Electrode System (FES): Towards Axial Dispersion and Velocity Profile
}

\author{
Djamel Ghernaout ${ }^{1,2 *}$, Noureddine Elboughdiri1,3, Saad Ghareba1,4, Alsamani Salih 1,5 \\ ${ }^{1}$ Chemical Engineering Department, College of Engineering, University of Ha'il, Ha'il, Saudi Arabia \\ ${ }^{2}$ Chemical Engineering Department, Faculty of Engineering, University of Blida, Blida, Algeria \\ ${ }^{3}$ Département de Génie Chimique de Procédés, Laboratoire Modélisation, Analyse, et Commande des systèmes, \\ Ecole Nationale d'Ingénieurs de Gabès (ENIG), Gabès, Tunisia \\ ${ }^{4}$ Department of Chemical and Petroleum Engineering, El Mergib University, Alkhums, Libya \\ ${ }^{5}$ Department of Chemical Engineering, Faculty of Engineering, Al Neelain University, Khartoum, Sudan \\ Email: ^djamel_andalus@hotmail.com
}

How to cite this paper: Ghernaout, D., Elboughdiri, N., Ghareba, S. and Salih, A. (2020) Disinfecting Water with the Carbon Fiber-Based Flow-Through Electrode System (FES): Towards Axial Dispersion and Velocity Profile. Open Access Library Journal, 7: e6238. https://doi.org/10.4236/oalib.1106238

Received: March 17, 2020

Accepted: April 5, 2020

Published: April 8, 2020

Copyright $\odot 2020$ by author(s) and Open Access Library Inc.

This work is licensed under the Creative Commons Attribution International License (CC BY 4.0).

http://creativecommons.org/licenses/by/4.0/

\section{(c) (i) Open Access}

\begin{abstract}
Electrochemical technology for the killing of pathogens has been largely investigated. Lately, $\mathrm{Ni}$ et al. [1] published excellent research on the disinfection efficiency of a carbon fiber-based flow-through electrode system (FES) versus Gram-negative bacteria (Escherichia coli and fecal coliform) and Gram-positive bacteria (Enterococcus faecalis and Bacillus subtilis) in normal saline over a large span of applied voltages $(1-5 \mathrm{~V})$ and hydraulic retention times (HRTs) (1 - $10 \mathrm{~s})$. They established that the Gram-negative microbes were more susceptible to FES for their thinner cell walls and over $6.5 \mathrm{log}$ reduction (no live bacteria found) was obtained at the applied voltage of $2 \mathrm{~V}$ and HRT of $2 \mathrm{~s}$; however, Gram-positive microbes were demobilized at slightly bigger voltages $(3 \mathrm{~V}, 2 \mathrm{~s})$ or longer HRTs $(2 \mathrm{~V}, 5 \mathrm{~s})$. Demobilizing microorganisms was related to the alteration and laceration of cell membranes mostly via anode direct oxidation in the absence of bacterial regrowth. Further, the disregarding formation of the free chlorine at low voltages $(\leq 2 \mathrm{~V})$ could avert the production of possible chlorinated disinfection by-products. Therefore, FES could furnish an undeveloped substitute to traditional disinfection processes for eliminating pathogens in water. This work concludes that focusing on axial dispersion and velocity profile inside anode will be very useful in comprehending the transport phenomena and proposing a fresh model that merges the axial dispersion and velocity profile for the FES. Such a research trend will more encourage the FES implementation at the large industrial level for disinfecting water.
\end{abstract}




\section{Subject Areas}

Chemical Engineering \& Technology

\section{Keywords}

Carbon Fiber Felt (CFF), Electrodisinfection, Gram-Negative Bacteria, Gram-Positive Bacteria, Axial Dispersion, Velocity Profile

\section{Introduction}

Disinfecting water efficaciously remains vital for treating water and wastewater. Traditional disinfection techniques comprise a separate or joint application of chlorination [1] [2], ultraviolet (UV) radiation [3] [4], and ozonation [5] [6]. Nevertheless, the preceding technologies stay alas followed by the generation of unwanted chlorinated disinfection by-products (DBPs) for chlorination [7], the formation of bromate and high-energy consumption for ozonation method [8], and the photoreactivation or dark repair for UV radiation [9]. Therefore, a low-energy consumption, high-efficiency, and chlorine-free demobilization technology has to be suggested as mohair to classical demobilization techniques.

Eliminating microorganisms via electrochemical technology has been largely investigated [10]. Such researches mostly focused on the level of disinfection efficiency [11], electrolyte composition [12], and the demobilization pathway of indirect oxidation with electro-generated oxidants (chlorine and reactive oxygen species) [13], or the direct oxidation of microbes [14]. Nevertheless, the indirect oxidation phenomenon via free chlorine unavoidably elevates the hazards of the production of unwanted DBPs [15] [16]. Consequently, killing microorganisms electrochemically via a direct oxidation technique at low voltage has attracted augmenting interest not long ago [1].

In terms of electrochemical engineering, the device arrangement remains substantial and mostly categorized as flow-by and flow-through setup [17] [18] [19]. Employing flow-by devices with plate electrodes stays restricted because of its small exposure area, which requests more plate electrodes number or longer residence period to attain efficacious killing [20]. Alternatively, the flow-through setup constitutes a typical reaction area, in which the polluted water goes along the internal zone of electrodes to ameliorate efficaciously the mass transfer phase [21]. In such a device, three-dimensional (3D) materials, like metal or carbonaceous porous electrodes, remain largely tested. As an illustration, a CuO-nanowire-modified copper foam with an elevated conductivity was tried as the electrode to remedy an influent ( $\sim 10^{7}$ colony-forming units (CFU)/mL bacteria in normal saline) at the operating voltage of $1 \mathrm{~V}$ applied by direct current (DC) power supply. It attained nearly 7 log elimination of bacteria (i.e., no live microbes observed) at the hydraulic retention time (HRT) of $7 \mathrm{~s}$ [22], which was low juxtaposed with chlorination [23], and flow-by electrodisinfection [24]. Nevertheless, the chemical in- 
stability of metal material would limit the service life of electrodes, which restricted the large usage of metal materials [1] [25].

The 3D carbonaceous materials, like carbon nanotube (CNT) sponge [26] and carbon fiber felt (CFF) [14], remain broadly employed as anode and/or cathode thanks to their elevated specific surface area, excellent electric conductivity, and chemical stability. Indeed, the CNT sponge attained outstanding killing pathogens' activity at the HRT of $5 \mathrm{~s}$ and voltage of $2 \mathrm{~V}$ [26]. Nevertheless, the intricate manufacture and elevated material price of CNT sponges limit the large-scale utilization. For the CFF, it can be maturely manufactured and commercially purchased with wanted thickness and elevated porosity, which is very advised to work as electrodes [1].

Liu et al. [14] established that the flow-through electrochemical technique with the CFF electrode may ensure the considerable reduction of Escherichia coli and low energy-consumption at the applied voltage under $3 \mathrm{~V}$ [14]. Nevertheless, there are numerous microbes in the water medium, comprising Gram-negative and Gram-positive bacteria, which differ mostly in the structure and composition of the cell membrane [27] [28], and possess various resistance to the disinfection technique [29]. Therefore, the dissimilarities of disinfection efficiency among Gram-negative and Gram-positive bacteria require to be more studied consistently. Moreover, it also requests to prove the regrowth/reactivation event of bacteria following electrodisinfection.

\section{Carbon Fiber-Based Flow-Through Electrode System (FES) for Killing Gram-Negative and Gram-Positive Bacteria}

Ni et al. [1] constructed a carbon fiber-based flow-through electrode system (FES) (Figure 1). They tested consistently the physicochemical properties of CFFs), like the morphology, electrical resistivity, void space portion, elemental composition, and specific surface area. They realized disinfection trials of FES against Gram-negative bacteria (E. coli and fecal coliform) or Gram-positive bacteria (Enterococcus faecalis and Bacillus subtilis), and free chlorine analysis in effluent at low applied voltages $(1-5 \mathrm{~V})$ and short HRTs (1 - $10 \mathrm{~s})$. They determined the modification of cell membranes before and after disinfection using scanning electron microscopy (SEM) analysis. They assessed the route of FES and the action of CFF cathode and anode via an in-situ sampling test. Further, the storage trial was performed to more clarify if the microorganisms would regrow after FES application.

The carbon fiber-based FES furnished efficient demobilization of bacteria ( $>6.5$ log reduction, no live bacteria found) at low applied voltages and short HRTs (Figure 2). Most importantly, Gram-negative bacteria (E. coli and fecal coliform) were totally demobilized at the applied voltage of $2 \mathrm{~V}$ and HRT of $2 \mathrm{~s}$; while bigger voltages $(3 \mathrm{~V}, 2 \mathrm{~s})$ or longer HRTs $(2 \mathrm{~V}, 5 \mathrm{~s})$ were required for the demobilization of Gram-positive bacteria (E. faecalis or B. subtilis) with comparatively thicker cell walls. The route of FES disinfection was anode direct oxidation, 


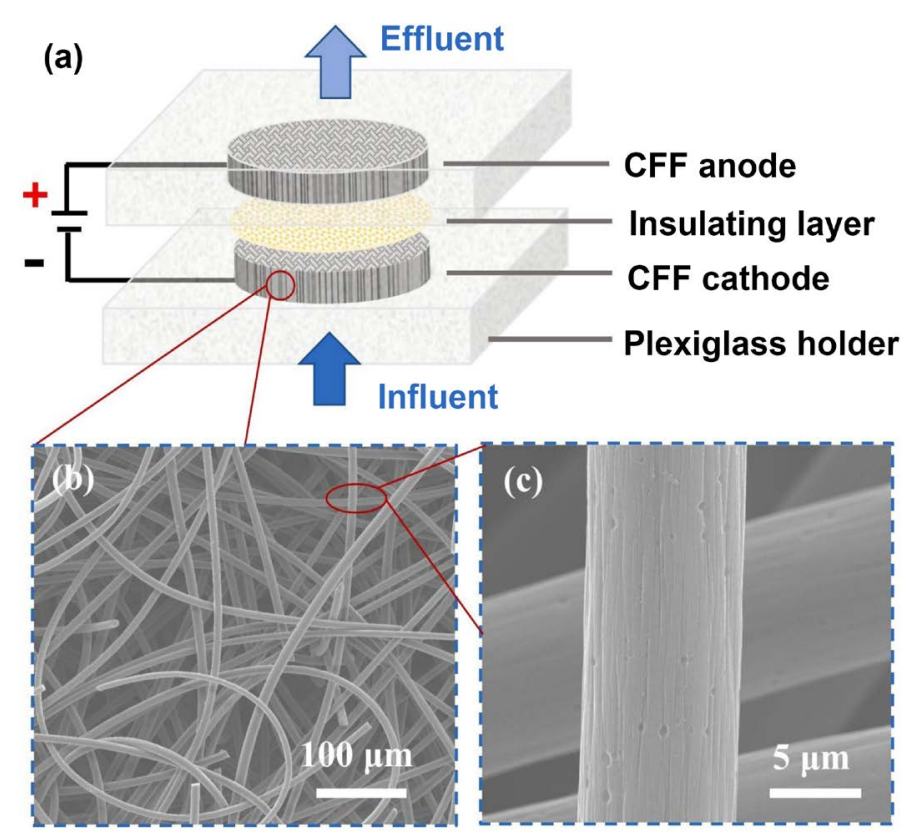

Figure 1. Construction and characterization of the flow-through electrode system (FES). (a) The schematic diagram of the FES including Plexiglas coaxial electrode holders, a filter paper as the insulating layer, and two CFF electrodes connected with the DC power supply. (b) Scanning electron microscopy (SEM) image of the micro-structure of CFF electrodes. (c) SEM image of the carbon fibers under high magnification [1].

conducting to the modifications and rupture of cell membranes. There was no important influence on bacterial demobilization via anode indirect oxidation of generating free chlorine at low voltage, which can avert the production of potential chlorinated DBPs. Further, it was as well illustrated that the bacteria were deteriorated irreversibly, and were unable to regrow throughout the storage procedure [1]. The global outstanding effectiveness of the carbon fiber-based FES presented a potential solution for emergency and rapid water disinfection.

From the disinfection findings aforesaid, it was mentioned that the Gram-positive bacteria were less defenseless to FES disinfection than Gram-negative bacteria. The distinction in elimination performance among two sorts of microbes may be related to the constitution of cell walls (peptidoglycan and teichoic acids) [1] [30] [31] [32] [33]. The peptidoglycan film of Gram-positive bacteria was much thicker, which was linked to their resistance [34]. However, the cells of Gram-negative microorganisms were not as robust as Gram-positive microorganisms and effortless to be demobilized for the thin peptidoglycan membrane with an outer membrane consisting of lipopolysaccharides and lipoproteins [27]. Moreover, FES depicted better efficiency towards B. subtilis rather than $E$. faecalis probably due to the cell size of $B$. subtilis (about $2.7 \pm 0.2 \mu \mathrm{m}$ in length) was much bigger than that of $E$. faecalis (about $0.9 \pm 0.3 \mu \mathrm{m}$ in length) determined by the SEM image (Figure $3(\mathrm{c})$, Figure $3(\mathrm{~d})$ ), which furnished much more contact area with the electrode surface for electrodisinfection. Further, the high-efficiency disinfection performance can remain for at least seven days [35]. 


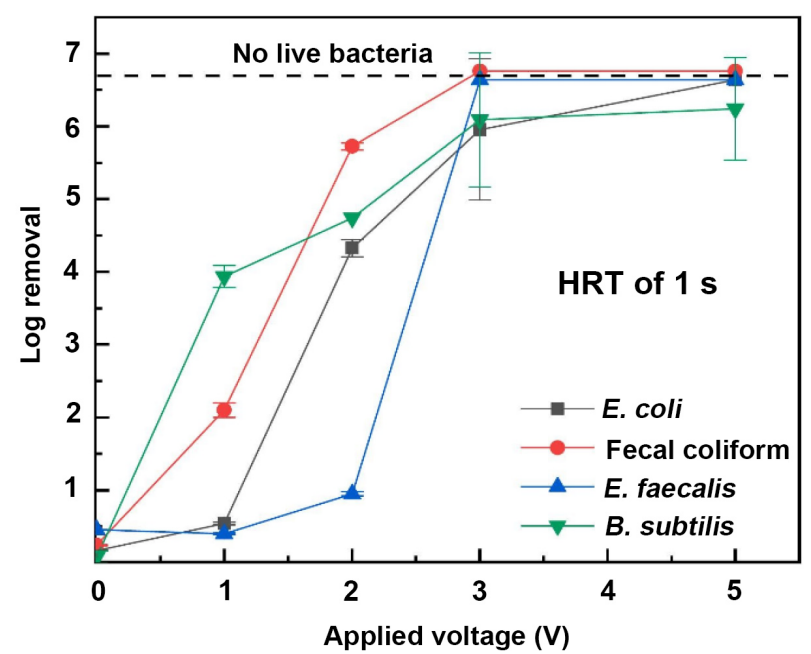

(a)

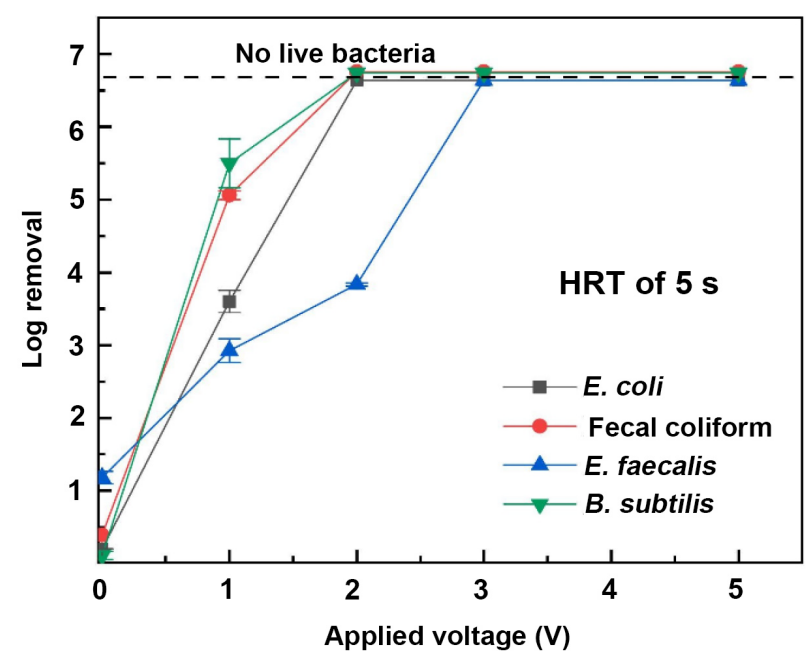

(c)

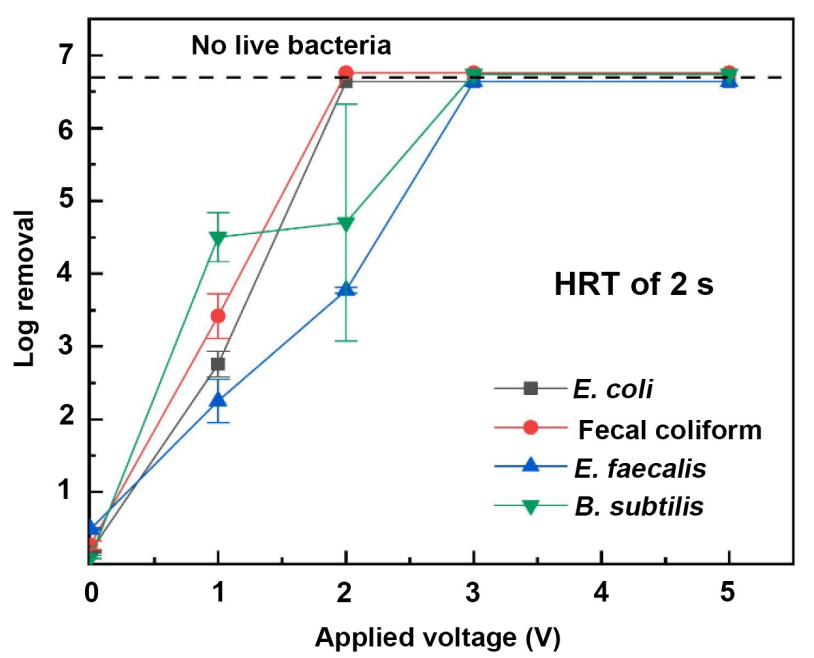

(b)

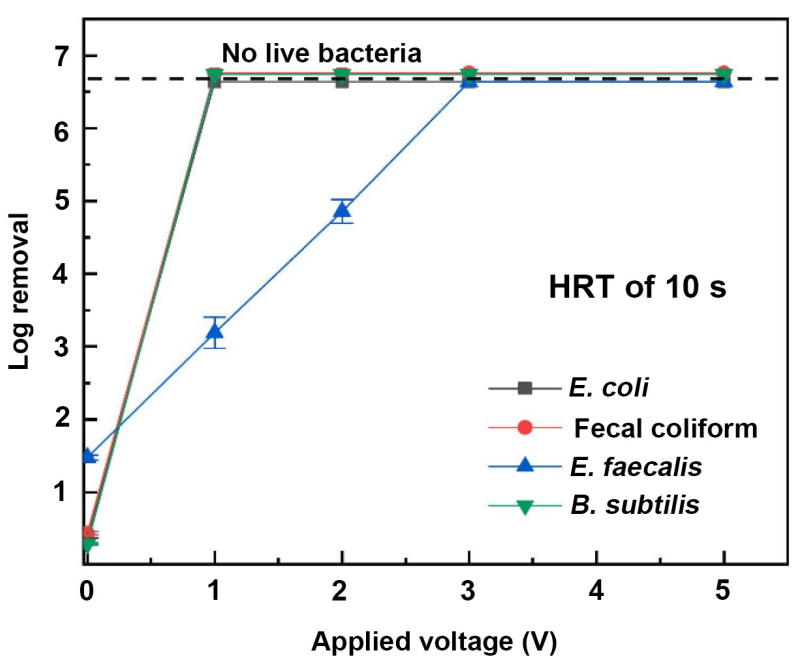

(d)

Figure 2. The disinfection performance of the carbon fiber-based FES towards four bacterial strains without and with the applied voltages of $1-5 \mathrm{~V}$ at the HRTs of $1 \mathrm{~s}(\mathrm{a}), 2 \mathrm{~s}(\mathrm{~b}), 5 \mathrm{~s}(\mathrm{c})$, and $10 \mathrm{~s}(\mathrm{~d})$ [1].

\section{Carbon Fiber-Based Flow-Through Electrode System (FES) Disinfection Pathway}

Figure 3 illustrates representative SEM images of E. coli, fecal coliform, E. faecalis, and B. subtilis before and following FES treatment. Most importantly, cell membranes of Gram-negative bacteria after a 2 V, 2 s treatment were dramatically dehydrated and broken juxtaposed to the untreated cells; however, the dead Gram-positive bacteria following a 3 V, 2 s treatment maintained relatively intact cell membrane structures, particularly for $E$. faecalis. The distinction between Gram-positive and Gram-negative microbes proposed that Gram-negative bacteria were relatively liable to electrodisinfection for the thinner cell walls. As a consequence, it was established that the route of bacterial death below FES treatment was the demolition of cell membranes [1]. 

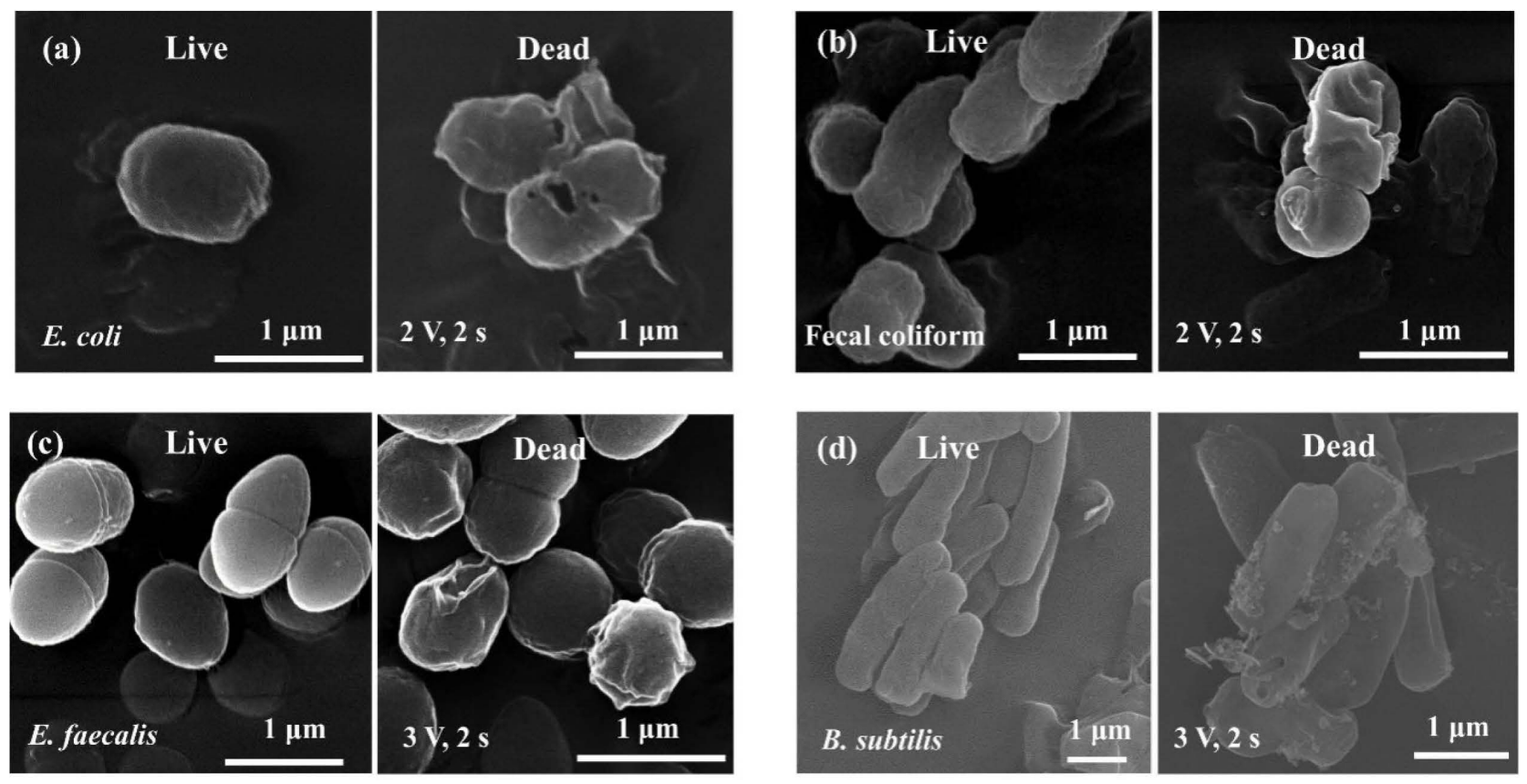

Figure 3. Morphology of live and dead bacteria. (a) The live and dead E. coli cells after a $2 \mathrm{~V}, 2 \mathrm{~s}$ treatment. (b) The live and dead fecal coliform cells after a 2 V, 2 s treatment. (c) The live and dead E. faecalis cells after a 3 V, 2 s treatment. (d) The live and dead B. subtilis cells after a $3 \mathrm{~V}, 2 \mathrm{~s}$ treatment [1].

Further, Ni et al. [1] focused more on the influent with $\sim 10^{6} \mathrm{CFU} / \mathrm{mL}$ E. coli to ascertain the pathway of FES disinfection technique. In an effort to recognize the role of anode and cathode, they performed the in-situ tests to reach the cells elimination following cathode treatment and successive cathode-anode treatment below $2 \mathrm{~V}$ and $3 \mathrm{~V}$, respectively.

As illustrated in Figure 4(a), the E. coli in the effluent samples was demobilized efficiently following consecutive cathode-anode treatment, and the disinfection effectiveness was enhanced with the elevation of the applied voltages and/or HRTs. Nevertheless, the reduction proportion $(\sim 31 \%)$ following only cathode treatment below $2 \mathrm{~V}$ was little and there was no evident role for cathode demobilization ( $33 \%$ reduction) with the augmentation of voltage (3 V) or HRT (10 s). Consequently, it is shown that the reaction at the anode controlled the disinfection performance of FES treatment, which was in conformity with former investigations [14] [36].

The likely route for anode electrochemical operation comprised direct oxidation and indirect oxidation via forming reactive species like hydroxyl radical ('OH) and free chlorine [10] [37] [38] [39] [40] [41]. Nevertheless, the small applied voltage of $2 \mathrm{~V}$ for $E$. coli demobilization was incapable to produce ${ }^{\circ} \mathrm{OH}$ which requested much bigger anode potential [42] [43], while the free chlorine with standard evolution potential of $1.15 \mathrm{~V}$ vs $\mathrm{Ag} / \mathrm{AgCl}$ was fit to take place in the FES treatment [1].

On the other hand, Ni et al. [1] followed the level of free chlorine produced throughout demobilization at changed applied voltages and HRTs (Figure 4(b)). 


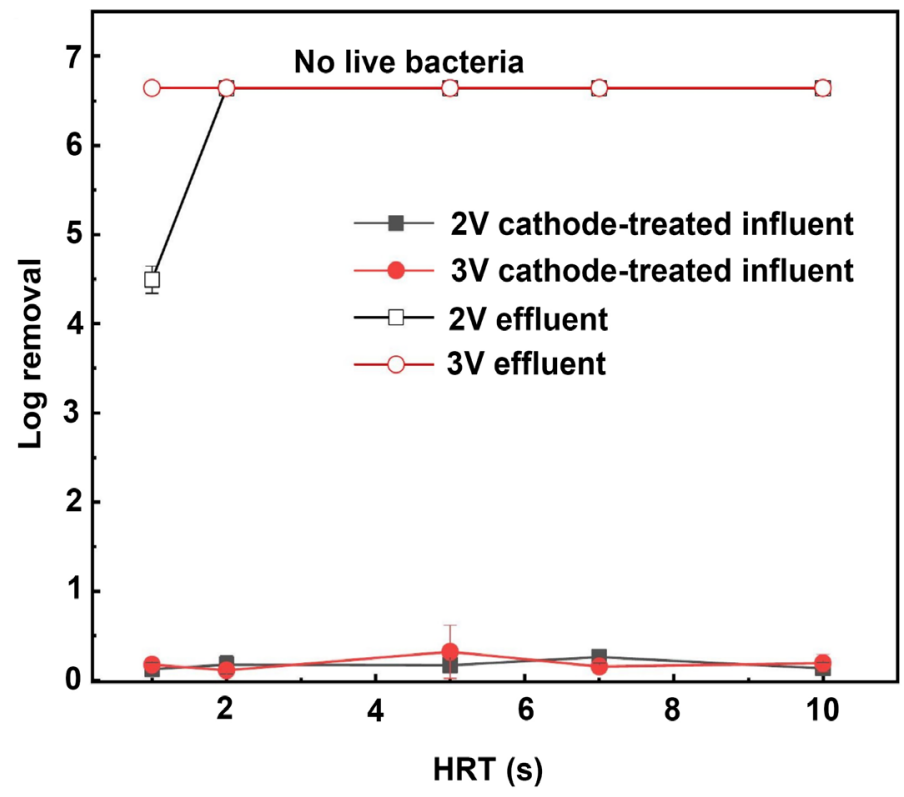

(a)

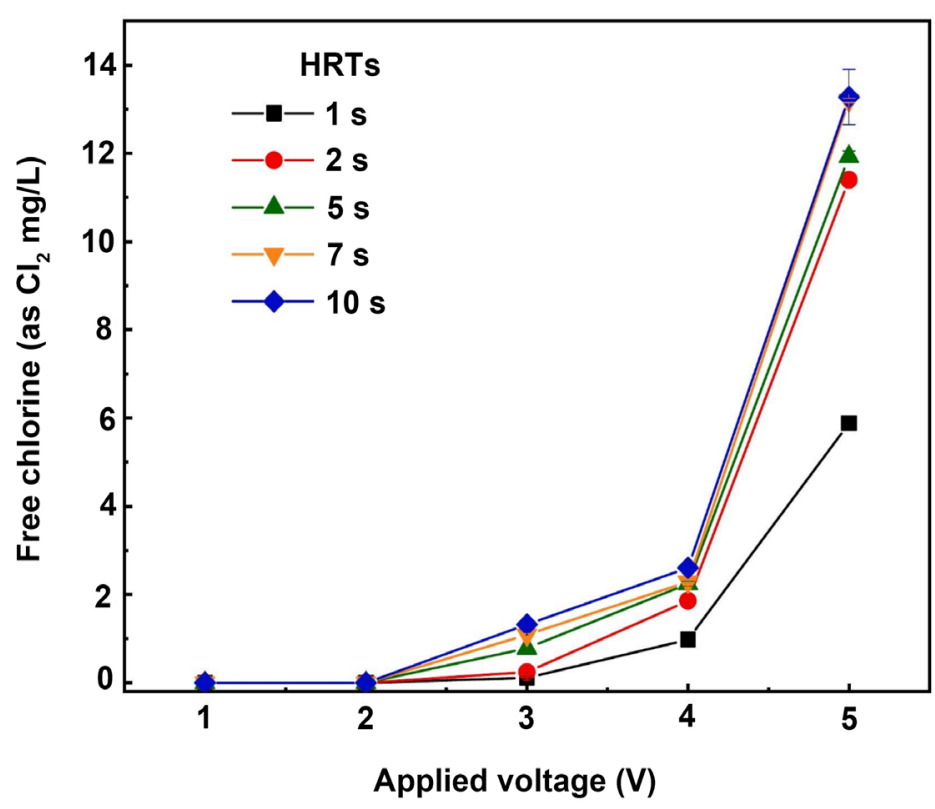

(b)

Figure 4. (a) The log reduction of $E$. coli in cathode-treated influent and effluent at diverse HRTs below applied voltages of $2 \mathrm{~V}$ and $3 \mathrm{~V}$. (b) The concentration of free chlorine in effluent at different applied voltages and HRTs [1].

There was no considerable formation of free chlorine (lower than the detection limit, $10 \mu \mathrm{g} / \mathrm{L}$ ) at the applied voltage under $2 \mathrm{~V}$ no matter how long the residence period was. Further, the level augmented with a bigger residence period at the higher applied voltages (over $3 \mathrm{~V}$ ). 
Considering the findings aforesaid, $\mathrm{Ni}$ et al. [1] concluded that demobilizing $E$. coli was mostly related to the anode direct impact at the applied voltage of $2 \mathrm{~V}$, instead of indirect oxidation via ${ }^{\circ} \mathrm{OH}$ and free chlorine generation. It also averted the production of potential chlorinated DBPs, which was apt to begin to be an encouraging substitutional for chlorination.

\section{Axial Dispersion and Velocity Profile for the FES}

As shown in Figure 1, influent enters the FES. It passes across the CFF cathode, an insulator layer, and CFF anode. In terms of electrochemical engineering, the main reactions occur in the CFF cathode and CFF anode. As mentioned above, bacterial demobilization was related to the alteration and rupture of the cell membrane mostly through anode direct oxidation without bacterial remobilization [1]. Therefore, what happens inside the anode via direct oxidation constitutes the main stage of electrodisinfection process. However, before the electrochemical reaction taking place, wastewater has to be put in contact with the surface anode. In other words, there is a mass transfer phase.

Indeed, the residence time distribution (RTD) remains a crucial feature in the exploration of non-ideal reactors [44]. In micro-reactors that work mostly below small Reynolds numbers, the axial dispersion is fundamental [44]. Because the channel length or residence time of fluid is frequently not long enough (from 2 to $5 \mathrm{~s}[1]$ ), the axial dispersion model cannot anticipate an exact RTD of the fluid in micro-reactors [44]. With a view to controlling such a problem, Fazli-Abukheyli and Darvishi [44] suggested a fresh model that integrates the axial dispersion and velocity profile employing the parallel tanks-in-series compartment model. The model includes two parameters, involving the velocity profile exponent and Peclet number. It may be employed for Newtonian and non-Newtonian fluid flow in the devices with a large span of Reynolds number and in all domains of flow regime, comprising plug, laminar, perfectly mixed, and different profiles among such regimes. Following validating the model, Fazli-Abukheyli and Darvishi [44] assessed the impacts of velocity profile and Peclet number on the RTD of fluid in the tube for m-laminar and y-laminar velocity profiles.

Rastegar and $\mathrm{Gu}$ [45] proposed a novel correlation for the axial dispersion coefficient employing experimental information in the literature for axial dispersion in fixed-bed columns packed with particles. The Chung and Wen correlation, the De Ligny correlation are two famous empirical correlations. Nevertheless, the former lacks the molecular diffusion term and the latter does not take into account bed voidage. Their novel axial dispersion coefficient correlation is founded on additional experimental data in the literature by taking into account both molecular diffusion and bed voidage. It is more comprehensive and accurate. The Peclet number correlation from the new axial dispersion coefficient correlation on the average leads to $12 \%$ lower Peclet number values compared to the values from the Chung and Wen correlation, and in many cases much smaller than those from the De Ligny correlation. 
Investigations, as performed by Fazli-Abukheyli and Darvishi [44] and Rastegar and $\mathrm{Gu}$ [45], will be consequently helpful in understanding the transport phenomena and suggesting a novel model that integrates the axial dispersion and velocity profile for the FES. For instance, Malayeria et al. [46] focused on modeling of gas-phase heterogeneous photocatalytic oxidation reactor in the occurrence of mass transfer limitation and axial dispersion. Such research would initiate the investigation field suggested here for coming works.

\section{Conclusions}

From this work, the following conclusions can be drawn:

1) Pure water supply remains one of the most vital and precious requests for human beings to continue, and the shortage of supply of potable water has been a grave problem during the last decades. The existence of pollutants like pathogens has the tendency to be the main worry for keeping nature and human life. There are several techniques being done on dealing with the polluted water; however, an optimum technology stays to be discovered. Nanotechnology has been earning currency in numerous fields especially in the implementation of water and wastewater remediation. The exceptional features of the nanomaterials composite formed are apt to give leap forward chances to metamorphose water and wastewater handling. Many of the nanotechnologies have shown their stunning characteristics in the water treatment industry. Additional amendment on such nanomaterials to enhance the features and decrease the effective price depicts an encouraging outlook of such carbon-based nanomaterials in the water and wastewater treatment field [47].

2) An investigation like performed by researchers [44] [45] will be very useful in comprehending the transport phenomena and proposing a fresh model that merges the axial dispersion and velocity profile for the FES. Such a research trend will more encourage the FES implementation at the industrial level for disinfecting water.

\section{Acknowledgements}

This research has been funded by the Research Deanship of University of Ha'il, Saudi Arabia, through the Project RG-191190.

\section{Conflicts of Interest}

The authors declare no conflicts of interest regarding the publication of this paper.

\section{References}

[1] Ni, X.-Y., Liu, H., Xin, L., Xu, Z.-B., Wang, Y.-H., Peng, L., Chen, Z., Wu, Y.-H. and Hu, H.-Y. (2020) Disinfection Performance and Mechanism of the Carbon Fiber-Based Flow-through Electrode System, (FES) towards Gram-Negative and Gram-Positive Bacteria. Electrochimica Acta. https://doi.org/10.1016/j.electacta.2020.135993 
[2] Muraca, P., Stout, J.E. and Yu, V.L. (1987) Comparative Assessment of Chlorine, Heat, Ozone, and UV Light for Killing Legionella pneumophila within a Model Plumbing System. Applied and Environmental Microbiology, 53, 447-453. https://doi.org/10.1128/AEM.53.2.447-453.1987

[3] Shah, A.D., Dotson, A.D., Linden, K.G. and Mitch, W.A. (2011) Impact of UV Disinfection Combined with Chlorination/Chloramination on the Formation of Halonitromethanes and Haloacetonitriles in Drinking Water. Environmental Science \& Technology, 45, 3657-3664. https://doi.org/10.1021/es104240v

[4] Linden, K.G., Shin, G.A., Faubert, G., Cairns, W. and Sobsey, M.D. (2002) UV Disinfection of Giardia lamblia Cysts in Water. Environmental Science \& Technology, 36, 2519-2522. https://doi.org/10.1021/es0113403

[5] Fang, J., Liu, H., Shang, C., Zeng, M., Mengling, N. and Liu, W. (2014) E.coli and Bacteriophage MS2 Disinfection by UV, Ozone and the Combined UV and Ozone Processes. Frontiers of Environmental Science \& Engineering, 8, 547-552. https://doi.org/10.1007/s11783-013-0620-2

[6] Mecha, A.C., Onyango, M.S., Ochieng, A. and Momba, M.N.B. (2017) Evaluation of Synergy and Bacterial Regrowth in Photocatalytic Ozonation Disinfection of $\mathrm{Mu}$ nicipal Wastewater. Science of the Total Environment, 601-602, 626-635.

https://doi.org/10.1016/j.scitotenv.2017.05.204

[7] Pan, Y., Zhang, X. and Zhai, J. (2015) Whole Pictures of Halogenated Disinfection Byproducts in Tap Water from China's Cities. Frontiers of Environmental Science \& Engineering, 9, 121-130. https://doi.org/10.1007/s11783-014-0727-0

[8] von Gunten, U. (2003) Ozonation of Drinking Water: Part II. Disinfection and by-Product Formation in Presence of Bromide, Iodide or Chlorine. Water Research, 37, 1469-1487. https://doi.org/10.1016/S0043-1354(02)00458-X

[9] Oguma, K., Katayama, H., Mitani, H., Morita, S., Hirata, T. and Ohgaki, S. (2001) Determination of Pyrimidine Dimers in Escherichia coli and Cryptosporidium parvum during UV Light Inactivation, Photoreactivation, and Dark Repair. Applied and Environmental Microbiology, 67, 4630-4637. https://doi.org/10.1128/AEM.67.10.4630-4637.2001

[10] Martínez-Huitle, C.A. and Brillas, E. (2008) Electrochemical Alternatives for Drinking Water Disinfection. Angewandte Chemie International Edition, 47, 1998-2005. https://doi.org/10.1002/anie.200703621

[11] Chen, S., Hu, W., Hong, J. and Sandoe, S. (2016) Electrochemical Disinfection of Simulated Ballast Water on $\mathrm{PbO}_{2} /$ Graphite Felt Electrode. Marine Pollution Bulletin, 105, 319-323. https://doi.org/10.1016/j.marpolbul.2016.02.003

[12] Rahaman, M.S., Vecitis, C.D. and Elimelech, M. (2012) Electrochemical Carbon-Nanotube Filter Performance toward Virus Removal and Inactivation in the Presence of Natural Organic Matter. Environmental Science \& Technology, 46, 1556-1564. https://doi.org/10.1021/es203607d

[13] Jeong, J., Kim, C. and Yoon, J. (2009) The Effect of Electrode Material on the Generation of Oxidants and Microbial Inactivation in the Electrochemical Disinfection Processes. Water Research, 43, 895-901. https://doi.org/10.1016/j.watres.2008.11.033

[14] Liu, H., Ni, X.Y., Huo, Z.Y., Peng, L., Li, G.Q., Wang, C., Wu, Y.H. and Hu, H.Y. (2019) Carbon Fiber-Based Flow-through Electrode System, (FES) for Water Disinfection via Direct Oxidation Mechanism with a Sequential Reduction-Oxidation Process. Environmental Science \& Technology, 53, 3238-3249. https://doi.org/10.1021/acs.est.8b07297 
[15] Ghernaout, D., Naceur, M.W. and Aouabed, A. (2011) On the Dependence of Chlorine by-Products Generated Species Formation of the Electrode Material and Applied Charge during Electrochemical Water Treatment. Desalination, 270, 9-22. https://doi.org/10.1016/j.desal.2011.01.010

[16] Brillas, E. and Martínez-Huitle, C.A. (2015) Decontamination of Wastewaters Containing Synthetic Organic Dyes by Electrochemical Methods. An Updated Review. Applied Catalysis B: Environmental, 166-167, 603-643. https://doi.org/10.1016/j.apcatb.2014.11.016

[17] Sires, I., Brillas, E., Oturan, M.A., Rodrigo, M.A. and Panizza, M. (2014) Electrochemical Advanced Oxidation Processes: Today and Tomorrow. A Review. Environmental Science and Pollution Research, 21, 8336-8367. https://doi.org/10.1007/s11356-014-2783-1

[18] Martinez-Huitle, C.A., Rodrigo, M.A., Sires, I. and Scialdone, O. (2015) Single and Coupled Electrochemical Processes and Reactors for the Abatement of Organic Water Pollutants: A Critical Review. Chemical Reviews, 115, 13362-13407. https://doi.org/10.1021/acs.chemrev.5b00361

[19] Castañeda, L.F., Walsh, F.C., Nava, J.L. and Ponce de León, C. (2017) Graphite Felt as a Versatile Electrode Material: Properties, Reaction Environment, Performance and Applications. Electrochimica Acta, 258, 1115-1139. https://doi.org/10.1016/j.electacta.2017.11.165

[20] Ghernaout, D., Badis, A., Ghernaout, B. and Kellil, A. (2008) Application of Electrocoagulation in Escherichia coli Culture and Two Surface Waters. Desalination, 219, 118-125. https://doi.org/10.1016/j.desal.2007.05.010

[21] Schoen, D.T., Schoen, A.P., Hu, L., Kim, H.S., Heilshorn, S.C. and Cui, Y. (2010) High Speed Water Sterilization Using One-Dimensional Nanostructures. Nano Letters, 10, 3628-3632. https://doi.org/10.1021/nl101944e

[22] Huo, Z.Y., Xie, X., Yu, T., Lu, Y., Feng, C. and Hu, H.Y. (2016) Nanowire-Modified Three-Dimensional Electrode Enabling Low-Voltage Electroporation for Water Disinfection. Environmental Science \& Technology, 50, 7641-7649.

https://doi.org/10.1021/acs.est.6b01050

[23] Diao, H.F., Li, X.Y., Gu, J.D., Shi, H.C. and Xie, Z.M. (2004) Electron Microscopic Investigation of the Bactericidal Action of Electrochemical Disinfection in Comparison with Chlorination, Ozonation and Fenton Reaction. Process Biochemistry, 39, 1421-1426. https://doi.org/10.1016/S0032-9592(03)00274-7

[24] Ghernaout, D. and Ghernaout, B. (2010) From Chemical Disinfection to Electrodisinfection: The Obligatory Itinerary? Desalination and Water Treatment, 16, 156-175. https://doi.org/10.5004/dwt.2010.1085

[25] Huo, Z.Y., Liu, H., Yu, C., Wu, Y.H., Hu, H.Y. and Xie, X. (2019) Elevating the Stability of Nanowire Electrodes by Thin Polydopamine Coating for Low-Voltage Electroporation-Disinfection of Pathogens in Water. Chemical Engineering Journal, 369, 1005-1013. https://doi.org/10.1016/j.cej.2019.03.146

[26] Huo, Z.Y., Luo, Y., Xie, X., Feng, C., Jiang, K., Wang, J. and Hu, H.Y. (2017) Carbon-Nanotube Sponges Enabling Highly Efficient and Reliable Cell Inactivation by Low-Voltage Electroporation. Environmental Science: Nano, 4, 2010-2017. https://doi.org/10.1039/C7EN00558J

[27] Beveridge, T.J. (2009) Use of the Gram Stain in Microbiology. Biotechnic \& Histochemistry, 76, 111-118. https://doi.org/10.1080/bih.76.3.111.118

[28] Budin, G., Chung, H.J., Lee, H. and Weissleder, R. (2012) A Magnetic Gram Stain for Bacterial Detection. Angewandte Chemie International Edition, 51, 7752-7755. https://doi.org/10.1002/anie.201202982 
[29] Racyte, J., Bernard, S., Paulitsch-Fuchs, A.H., Yntema, D.R., Bruning, H. and Rijnaarts, H.H. (2013) Alternating Electric Fields Combined with Activated Carbon for Disinfection of Gram Negative and Gram Positive Bacteria in Fluidized Bed Electrode System. Water Research, 47, 6395-6405. https://doi.org/10.1016/j.watres.2013.08.011

[30] Ghernaout, D., Alghamdi, A. and Ghernaout, B. (2019) Microorganisms' Killing: Chemical Disinfection vs. Electrodisinfection. Applied Engineering, 3, 13-19.

[31] Ghernaout, D. (2017) Microorganisms' Electrochemical Disinfection Phenomena. EC Microbiology, 9, 160-169.

[32] Ghernaout, D. and Elboughdiri, N. (2020) Electrocoagulation Process in the Context of Disinfection Mechanism. Open Access Library Journal, 7, e6083. https://doi.org/10.4236/oalib.1106083

[33] Ghernaout, D. (2019) Disinfection via Electrocoagulation Process: Implied Mechanisms and Future Tendencies. EC Microbiology, 15, 79-90.

[34] Loraine, G., Chahine, G., Hsiao, C.T., Choi, J.K. and Aley, P. (2012) Disinfection of Gram-Negative and Gram-Positive Bacteria Using DynaJets ${ }^{\circledast}$ Hydrodynamic Cavitating Jets. Ultrasound and Sonochemistry, 19, 710-717. https://doi.org/10.1016/j.ultsonch.2011.10.011

[35] Ni, X.Y., Liu, H., Wang, C., Wang, W.L., Xu, Z.B., Chen, Z., Wu, Y.H. and Hu, H.Y. (2020) Comparison of Carbonized and Graphitized Carbon Fiber Electrodes under Flow-through Electrode System, (FES) for High-Efficiency Bacterial Inactivation. Water Research, 168, 115150. https://doi.org/10.1016/j.watres.2019.115150

[36] Hong, S.H., Jeong, J., Shim, S., Kang, H., Kwon, S., Ahn, K.H. and Yoon, J. (2008) Effect of Electric Currents on Bacterial Detachment and Inactivation. Biotechnology \& Bioengineering, 100, 379-386. https://doi.org/10.1002/bit.21760

[37] Martínez-Huitle, C.A. and Panizza, M. (2018) Electrochemical Oxidation of Organic Pollutants for Wastewater Treatment. Current Opinion in Electrochemistry, 11, 62-71. https://doi.org/10.1016/j.coelec.2018.07.010

[38] Ghernaout, D. and Elboughdiri, N. (2019) Mechanistic Insight into Disinfection Using Ferrate(VI). Open Access Library Journal, 6, e5946.

https://doi.org/10.4236/oalib.1105946

[39] Ghernaout, D. and Elboughdiri, N. (2019) Water Disinfection: Ferrate(VI) as the Greenest Chemical: A Review. Applied Engineering, 3, 171-180.

[40] Ghernaout, D., Touahmia, M. and Aichouni, M. (2019) Disinfecting Water: Electrocoagulation as an Efficient Process. Applied Engineering, 3, 1-12.

[41] Ghernaout, D., Aichouni, M. and Touahmia, M. (2019) Mechanistic Insight into Disinfection by Electrocoagulation: A Review. Desalination and Water Treatment, 141, 68-81. https://doi.org/10.5004/dwt.2019.23457

[42] Kapałka, A., Fóti, G. and Comninellis, C. (2009) The Importance of Electrode Material in Environmental Electrochemistry: Formation and Reactivity of Free Hydroxyl Radicals on Boron-Doped Diamond Electrodes. Electrochimica Acta, 54, 2018-2023. https://doi.org/10.1016/j.electacta.2008.06.045

[43] Singla, J., Sangal, V.K., Singh, A. and Verma, A. (2020) Application of Mixed Metal Oxide Anode for the Electro-Oxidation/Disinfection of Synthetic Urine: Potential of Harnessing Molecular Hydrogen Generation. Journal of Environmental Management, 255, Article ID: 109847. https://doi.org/10.1016/j.jenvman.2019.109847

[44] Fazli-Abukheyli, R. and Darvishi, P. (2019) Combination of Axial Dispersion and Velocity Profile in Parallel Tanks-in-Series Compartment Model for Prediction of 
Residence Time Distribution in a Wide Range of Non-Ideal Laminar Flow Regimes. Chemical Engineering Science, 195, 531-540.

https://doi.org/10.1016/j.ces.2018.09.052

[45] Rastegar, S.O. and Gu, T. (2017) Empirical Correlations for Axial Dispersion Coefficient and Peclet Number in Fixed-Bed Columns. Journal of Chromatography A, 1490, 133-137. https://doi.org/10.1016/j.chroma.2017.02.026

[46] Malayeri, M., Lee, C.-S., Haghighat, F. and Klimes, L. (2020) Modeling of Gas-Phase Heterogeneous Photocatalytic Oxidation Reactor in the Presence of Mass Transfer Limitation and Axial Dispersion. Chemical Engineering Journal, 386, Article ID: 124013. https://doi.org/10.1016/j.cej.2020.124013

[47] Thines, R.K., Mubarak, N.M., Nizamuddin, S., Sahu, J.N., Abdullah, E.C. and Ganesan, P. (2017) Application Potential of Carbon Nanomaterials in Water and Wastewater Treatment: A Review. Journal of the Taiwan Institute of Chemical Engineers, 72, 116-133. https://doi.org/10.1016/j.jtice.2017.01.018 